\title{
ANALYSIS OF THE IMPACT OF SMALL AND MEDIUM SCALE ENTERPRISES ON ECONOMIC GROWTH IN NIGERIA (1981-2019)
}

\section{SUNDAY ALADE AGBONJINMI ${ }^{{ }^{*}}$, SAMUEL OLUSEGUN BEWAJI ${ }^{2}$ AND SUNDAY TIMOTHY OMOJUYIGBE ${ }^{3}$}

\author{
${ }^{1 *}$ Department of Economics, University of Abuja, Abuja, Nigeria. \\ ${ }^{2}$ Department of Economics, University of Abuja, Abuja, Nigeria. \\ ${ }^{3}$ Department of Economics, Veritas University, Abuja, Nigeria.
}

Correspondence Email: samuelbewaji@gmail.com; 09057517411.

\begin{abstract}
This research work analyzed the economic impact of small and medium scale enterprises in Nigeria and its contribution to the real gross domestic product (RGDP). The research covers the period of 39years (1981-2019). The researchers used secondary data that were sourced from Central Bank of Nigeria (CBN) and National Bureau of Statistics (NBS). Error Correction Model was used in analyzing the data and determining the long run relationship of small and medium scale enterprises on economic growth in Nigeria. The result indicated that there is a positive and significant relationship between (RGDP) and small and medium scale enterprises (SMEQ) in Nigeria, and the two null hypotheses were rejected. The impact of small and medium enterprises in Nigeria is way below expectation and the researchers therefore examined the credibility of the statement. Seeing that all Nigerian Government Development Agenda of the past and present leaders include small and medium scale enterprises promotion and development, there is need to ensure the development of the sector as the bedrock of economic growth and comparative advantage is visible. Therefore, it is concluded that, the different tiers of government should direct credit policies towards small and medium scale enterprises and intensify monitoring process to check inefficiency and ineffectiveness.
\end{abstract}

Keyword: SMEs and Nigeria Economic growth. 


\section{INTRODUCTION}

\subsection{Background to the study}

Economic growth is a key policy objective of any government. In addressing the pertinent issues in economic management, experts and economic planners have had to choose between or combine some of the macroeconomic variables. Economic growth, proxies by Gross Domestic Product (GDP) confers many benefits which include raising the general standard of living of the populace as measured by per capita national income, making income distribution easier to achieve, and by increasing the aggregate output through small and medium enterprises in the country.

Prior to the discovery of petroleum product in 1958, Nigeria was among the countries in Africa that encouraged agricultural production. However, the discovery of petroleum product has made government, companies and individuals to rely on petroleum as the major source of gross domestic product (GDP) in the country and perhaps neglecting other cradles of national income. According to Olutunla and Obamuyi (2008), the small and medium enterprises (SMEs) in Nigeria are a very heterogeneous group of business, usually operating in different sectors of the economy. In other words, small and medium enterprises are very fundamental for the Nigerian economy. Odeyemi (2003) also opined that those engaged in the distributive trade constitute about $50 \%$ of the SMEs, $10 \%$ are in manufacturing, $30 \%$ in agriculture and $10 \%$ in services, which together account for less than $50 \%$ of Nigerian Gross Domestic Product.

The latent contributions which small business can make are now attracting recognition. This awareness is manifest in the ever increasing number of Nigerians who daily strive to put up their personal ideas and abilities to effective use (by starting small business ventures) (Asta 2010). Evidence around the world indicate that small scale enterprise provide an effective means of stimulating indigenous entrepreneurship, enhancing greater employment opportunities per unit of capital invested and aiding the development of technology (Cabbelo, 2010).

Accordingly, due to the recognition of the roles of small business, the Nigerian government has since 1970 initiated programmes for the assistance of small businesses, especially, in the areas of finance, extension and advisory services including, training and provision of infrastructures (NBS 2009). All these are designed to enhance the development of small businesses. Successive governments in Nigeria have for the past three decades shown great interest in the other credit agencies/schemes to provide customized funding (Akinruwa, et.al, 2013). However, for entrepreneurs small scale enterprise to play an appropriate role of increasing the aggregate output, reducing poverty level and reducing the high rate of unemployment in the country, government needs to provide security, and provide financial assistance for entrepreneurs in the country. Therefore, it is on this ground that this study is employing the following questions such as; what is the impact of small and medium scale enterprises output on economic growth in Nigeria? What is the impact of commercial loan and advances to small and medium scale enterprises output on economic growth in Nigeria? What is the impact of savings on small and medium scale enterprise in Nigeria? What is the impact of Agricultural contribution to small and medium scale enterprise in Nigeria? What is the impact of Foreign Direct Investment contribution to small and medium scale enterprise in Nigeria and also the impact of Agricultural output to economic growth in Nigeria? 


\subsection{Statement of Problem}

Nigeria's vision of being counted among the first twenty economies in the world by the year 2020 cannot be attained in a socio-economic milieu of hunger, poverty and unemployment among a large segment of its population except we change our economy face from consumption economy to productive economy through SMEs. Small and Medium Scale Enterprises are among the most recent attempts to solve some of the country's macro economic problems such as high rate of poverty and high rate of unemployment. One of the major obstacles facing small and medium scale enterprises is their inability to source for micro-credit to carry out their businesses (Akinruwa, 2013). This is due to lack of microcredit or lack of awareness about the existence of micro-credit scheme of community banks, deposit money banks, the merchant and other financial institutions. It is on this background that this study would be conducted to proffer solutions to some of the problems encountered by entrepreneurs to manage their small and medium enterprises in obtaining the credit to improve and to expand their businesses through commercial banks loans, foreign direct investment in order to analyse the impact of SMEs on the economic growth in the country.

\subsection{Statement of Hypothesis}

The following hypothesis for the study is stated in a null form:

Ho $_{1}$ : There is no significant impact of small and medium scale enterprises on economic growth in Nigeria.

$\mathbf{H O}_{2}$ : There is no long run significant impact of small and medium scale enterprises output on economic growth in Nigeria.

\subsection{Significance of the study}

A considerable amount of research has found that SMEs activities have affected the real output, quite recently, Safiriya (2012) examined the effects of Small and Medium Scale Enterprises on output and economic growth and attempted to answer why the current rise in SMEs activities have had smaller effects on output in recent time. Kwanashi (2010) provided a variety of estimates of the degree of transmission from SMEs to growth over time for a set of developing countries. Moreover, Ojo (2009) examined the role of SMEs in Nigeria and how SMEs have led to economic growth using least squares.

From the literature reviewed, most of the studies did not examine the transmission mechanism of how loans to SMEs affect SMEs output which will also have antecedent effect on Economic Growth. In other words, SME loans pass through to economic growth via SME output and this is adequately analyzed by the data from (1981-2019) used in this research work. Also the study is motivated by the fact that Nigeria relies on SMEs, which is a source of employment especially in the informal sector.

\subsection{Concept of Economic Growth}

\section{LITERATURE}

Economic growth as a concept is viewed differently by different scholars. This is attributed to the condition prevailing at the time of these scholars. Majority accept it as an increase in the level of national income and output of a country. According to Reavley and Lituchy (2008), it implies an increase in the net national product in a given period of time. He explained that economic growth is generally referred to as a quantitative change in economic variables, 
normally persisting over successive periods. He added that determinants of economic growth are availability of natural resources, the rate of capital formation, capital-output ratio, technological progress, dynamic entrepreneurship and other factors.

On the other hand, the Central Bank of Nigeria in its monetary policies circular No 22 of 2014 view small scale industry as those enterprises which have annual turnover not exceeding 500,000 naira (CBN Report, 2014). Similarly in 1990, the Federal Government of Nigeria defined small scale enterprises for the purpose of commercial bank loans as those enterprises whose annual turnover does not exceed 500,000 (five hundred thousand naira) for merchant bank loan to those enterprises with capital investment not exceeding 2 million naira) excluding the cost of land) or a minimum of 5 million naira.

\subsection{Previous Studies}

Bello, Jibir and Ahmed (2018) examined the impact of small and medium scale enterprises on economic growth of Nigeria using time series data spanning between 1986 and 2016. The data is obtained from the statistical bulletin published by the Central Bank of Nigeria (CBN). Regression analysis is employed for interpretation and analysis of the data collected for the study. The finding of the study reveals a positive and significant relationship between small and medium scale enterprises and output growth indicating that small and medium scale enterprises in Nigeria make positive contribution towards the development of Nigerian economy.

Otugo, Edoko, and Ezeanolue (2018) examined the effect of small and medium enterprises on economic growth in Nigeria using Ordinary Least Square (OLS) to regress data collected on government expenditure in promoting SMEs, Employment generation growth rate and level of corruption. From analysis of the study, it is observed that small and medium enterprise, government expenditure to small and medium enterprises, employment generations, commercial bank credit to small and medium enterprise and lending rate to small and medium enterprises have a positive impact on economic growth in Nigeria. Corruption has a negative impact on economic growth in Nigeria. However, all the explanatory variables have significant impacts on economic growth in Nigeria.

Snodgrass and Biggs (2014) concluded an empirical analysis on the impact of the Khushhali Microfinance Bank in Pakistan. The analysis demonstrated that participation in the scheme had positive impact on both economic and social indicators as well as income generating activities especially for the poor ones. The highest aggregate impacts of the programme on income generating activities were to SMEs and again these positive impacts were higher for the poor borrowers. These findings challenged what seems to have become conventional wisdom i.e. that micro-credit is not effective for the poor to increase their participation in activities such as SMEs.

Etebefia and Akinkunmi (2013) likewise examined the contribution of small scale industries to the national economy with regression and spearman's moment correlation analysis. Their findings were based on annual data of 1992 to 2007 and observed that there is a strong positive relationship between establishment and employment created. According to their study, the growth of the national economy of Nigeria depends on how vast that small scale industries are in technology and in their ability to overcome the Nigerian factors that may rise 
against. In their view "the more small scale industries (SSIs) we have the more employment created in the Nigeria economy system".

Onakoya, Fasanya and Abdurrahman (2013) examined the impact of financing small scale enterprises on economic growth using quarterly time series data from 1992 to 2009 using OLS. The result shows that loan to small scale entrepreneurs has a positive impact on the economic performance.

Muritala (2012) carried out a study investigating the importance of finance to the growth of SMEs and the impact of small and medium scale enterprises on economic growth. A survey method was used to gather data from 200 SME entrepreneurial managers from the selected local governments in Nigeria using a structured questionnaire and analyzed with several descriptive statistics. The results of the study concludes that lack of financial support, also with poor management, corruption, lack of training and experience, poor amenities among others as the most common hindrances to small and medium scale business growth in Nigeria. The conclusion is that financial support play a vital role in measuring the performance of small and medium scale business in Nigeria which is very commendable and in line with the expectation of this study.

Afolabi (2011) investigated the effect of SMEs financing on economic growth in Nigeria between 1980 and 2010. The study employed ordinary least square (OLS) method to estimate the multiple regression model. The estimated model results revealed that SMEs output proxy by wholesale and retail trade output as a component of gross domestic product, commercial banks credit to SMEs and exchange rate of naira vis-à-vis U.S dollar exert positive influence on economy development proxy real gross domestic product while lending rate is found to exert negative effects on economic growth. In terms of partial significance and using tstatistics as a test of evaluation, SMEs output and commercial banks, credit to SMEs were found to be significant factors enhancing-economic growth in Nigeria at 5\% critical level. Therefore, emanating from the findings, the study proffered that the central authority should create an enabling environment for SME development. The study of Afolabi (2011) was in line with the apriori expectation for this study.

Agu, and Okot (2011) investigated the impact of small and medium scale enterprises on economic growth in Nigeria between the period 1980 and 2009. The data were analyzed using ordinary Least Square (OLS) technique after the test of Co-integration suggested a long-run relationship between small and medium scale enterprises and economic growth. The estimated results point that small and medium scale enterprises have both positive and significant impact on economic development in Nigeria. The result further shows how significant SMEs are to economic growth of any country.

Onyeiwu (2010) studied small and medium enterprises finance and economic development of Nigeria, examines the effect of small and medium enterprises financing on the economic growth of Nigeria. In doing this, the Ordinary Least Square Method (OLS), Error Correction and Parsimonious Models are used to analyze quarterly data between 1994 and 2008. The result of the analysis shows that loans to SMEs and other variable except money supply and deficit financing exert a positive impact on GDP growth, and concluded that, Government has to find a way to encourage financial institutions to lend to SMEs by providing guarantees, interest rate subsidies and other incentives and which is to ensure proper capitalization of specialized agencies set up for SMEs financing but such agencies must be self-sustaining by 
raising funds, from the financial market and may participate in the equity of SMEs. Therefore, the study justified the fact that entrepreneurs depend so much on loans to finance their businesses.

\subsection{Theoretical Framework}

Observations regarding the nature and cause of economic growth are of considerable interest here, various economic growth models exist but this study adopted the neo-classical growth model.

\section{Neo-classical growth models.}

Robert Solow's (1974) pioneering contribution to growth theory has generated the theoretical basis for growth accounting. Criticizing the Harrod-Domar, economist Rober Solow has developed a new theory that is named as Neo-Classical Solow Model. According to Solow, if capital production ratio and capital output ratio is considered as flexible, the economy will reach into a stable position automatically.

The basic assumptions of the neo-classical growth model are as follows:

The productive capacity of the economy can be adequately characterized by constant returns to scale of production with diminishing return to capital and labour. Firms are price takers in a competitive market place. Technology change is entirely exogenous.

The framework of this study assures a standard neo-classical production function which begins from a premise that changes in quantities of factors of production account for growth in the economy. In this neo-classical view, we can thus decompose the contribution to output growth of the growth rates of inputs such as technology, capital, labour, savings, loans, or by incorporating a vector of additional variables in the estimating equation, such as loans, savings, interest rate, etc. However, it is obvious that neo-classical theory laid much emphasis on the impact of finance on economic growth of any country which serves as the link between this study and the theory.

\subsection{Method of Data Analysis}

\section{METHODOLOGY}

The statistical properties of the series are analyzed with the Augmented Dickey-Fuller (ADF) test of non-stationary to detect the presence of Unit Root and determine the order of integration of the series. Conventional regression analysis with time series data is done under the assumption that the series are stationary over time (Gujarati, 2001). Error correction model (ECM) was used to capture the long run impact of the independent variables on the dependent variable.

\subsection{Model Specification}

Afolabi (2011) applied the Cobb-Douglas production function to examine the relationship between small and medium scale enterprises financing and economic growth in Nigeria. Based on the theoretical framework and objective of the study, the model in Afolabi (2011) was specified and adapted with little modifications. But the distinctive feature of the model in this study is that Commercial loans and Advances to SME, savings and interest rates are factors inputs of the production function. Also the Service sector output was used as a proxy for output of SMEs unlike wholesale and retail output used by Afolabi (2011). The model 
carries two equations to show distinctively the relationship between SMEs and economic growth. The choice of this model is based on its flexibility and general acceptability.

The functional model:

$\mathrm{RGDP}_{\mathrm{t}}=\mathrm{f}(\mathrm{SMEQ}, \mathrm{INTR}, \mathrm{SAV}, \mathrm{AGRC}, \mathrm{FDI}, \mathrm{CLA})$

Introduce parameter and error term respectively $(\alpha, \beta, \mathrm{u})$

$\mathrm{RGDP}_{\mathrm{t}}=\alpha+\beta_{1} \mathrm{SMEQ}_{\mathrm{t}}+\beta_{2} \mathrm{INT}_{\mathrm{t}}+\beta_{3} \mathrm{SAV}_{\mathrm{t}}+\beta_{4} \mathrm{AGC}_{\mathrm{t}}+\beta_{5} \mathrm{FDI}_{\mathrm{t}}+\beta_{6} \mathrm{CLA}_{\mathrm{t}}+\mathrm{u}-------3.2$

Where:
$R G D P=$ Real gross domestic product
$S M E Q=$ SMEs output proxy by service sector output as a component of GDP
$C L A=$ Commercial Loans and Advances to SMEs
SAV = Savings in the economy
$I N R T=$ Interest rate
$A G R C=$ Agricultural Contribution to GDP
$F D I=$ Foreign Direct Investment
$\alpha=$ Intercept or constant
$\beta=$ Parameters or Co-efficient of explanatory variables
$u=$ Error term.

\section{Error Correction Model}

We therefore formulate our supposed unrestricted ECM model from which we obtain efficient lag-length necessary for estimation thus:

$$
\begin{aligned}
& \triangle \text { RGDP } \\
& =a_{0}+\sum_{i=1}^{a}\left(\partial_{0} \Delta \mathrm{RGDP}_{\mathrm{t}-1}\right)+\sum_{\mathrm{i}=0}^{\mathrm{b}} \partial_{1} \Delta \mathrm{SMEQ}_{\mathrm{t}-1}+\sum_{\mathrm{i}=0}^{\mathrm{c}} \partial_{2} \Delta \mathrm{INT}_{\mathrm{t}-1}+\sum_{\mathrm{i}=0}^{\mathrm{d}} \partial_{3} \Delta \mathrm{SAV}_{\mathrm{t}-1}+ \\
& \sum_{\mathrm{i}=0}^{\mathrm{e}} \partial_{4} \Delta \mathrm{AGRC}_{\mathrm{t}-1}+\sum_{\mathrm{i}=0}^{\mathrm{f}} \partial_{5} \Delta \mathrm{FDI}_{\mathrm{t}-1}+\sum_{\mathrm{i}=0}^{\mathrm{g}} \partial_{6} \Delta \mathrm{CLA}_{\mathrm{t}-1}+\text { ?]ECM } M_{t} \ldots \ldots \ldots \ldots \ldots \ldots . . . . . . .3
\end{aligned}
$$

\subsection{Sources of Data}

The study adopts secondary method of data collection of time series data needed for research estimation. The sources of the data are: National Bureau of Statistics (NBS) Annual Reports and Publications; Central Bank of Nigeria (CBN) Statistical Bulletin (2020), Journals, Bullions, Small and Medium Enterprises Development Agency (SMEDAN), Bank of Industry (BOI) Publications, publications from Nigeria Economic Society (NES) and so on.

\section{RESULTS AND DISCUSSION}

\subsection{Summary Statistics}

The Summary statistics as derived through E-Views 9.0 shows the Mean, Median, Maximum, Minimum, Standard Deviation, Skewedness, Kurtosis, Jacque-Bera and Probability of each of the variables as presented below: 


\begin{tabular}{|c|c|}
\hline $\mathbf{F}$ & 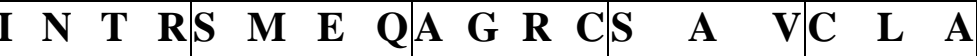 \\
\hline 391 & \begin{tabular}{l|l|l|l|l|l|l|l|}
6 & 1 & $11,850.01$ & $7,944.46$
\end{tabular} \\
\hline \begin{tabular}{ll|l}
8 & 0 & 1 \\
\end{tabular} & 0.978 \\
\hline 31.4529 & 953.7923 \\
\hline $13,799.2622$ & $68.442,303.513$ \\
\hline \begin{tabular}{|l|l|l|l|}
$21,325.44$ & $5,527.50 \mid$
\end{tabular} & \begin{tabular}{|l|l|l|l|l|l|}
6 & $9,450.525,328.454$
\end{tabular} \\
\hline $\operatorname{vness} 0$ & \begin{tabular}{ll|l}
5 & 6 & 1
\end{tabular} \\
\hline o s is 2 & \begin{tabular}{ll|l}
7 & 7 & 4
\end{tabular} \\
\hline 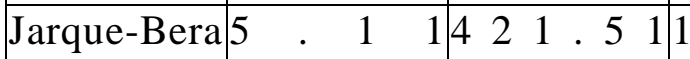 & \begin{tabular}{ll|l}
8 & 3 & 5
\end{tabular} \\
\hline robability 0 & $0 \quad .560$ \\
\hline \begin{tabular}{ll|l|l|l|}
$5,418.00$ & $91,314.30$ & 1,3 \\
\end{tabular} & 686 \\
\hline \begin{tabular}{|l|l|l|l|} 
Dev. $17,300,000,000.00$ & 1,16 \\
\end{tabular} & \begin{tabular}{ll|l}
0.00 & 1,08 \\
\end{tabular} \\
\hline vations 3 & 93 \\
\hline
\end{tabular}

Source: Author's own computation using E-Views Software, Version 9.0

It was observed from the above normality test with reference to the Jarque-Bera estimates and probability value that AGRC, SAV, FDI and SME output (SMEQ) are variables which are not normally distributed due to their low probability values of $0.01,0.00,0.001$ and 0.04 respectively which are lower than the probability value of 0.05 .

On the other hand it was observed that the probability values for gross domestic product, INT, RGDP, CLA were normally distributed due to their high probability value of $0.56,0.08$, 0.07 which are higher than the probability of 0.05 . 


\subsection{Data Analysis}

4.2. Unit Root Test (Check Unit Root Appendix for detail)

Table 4.2 UNIT ROOT TEST (Augmented Dickey Fuller Test)

\begin{tabular}{|c|c|c|c|c|c|c|c|c|c|}
\hline Variable & \multirow{4}{*}{$\begin{array}{l}\text { L e v e l s } \\
-1.087102\end{array}$} & \multicolumn{2}{|c|}{ Critical Values } & \multirow{4}{*}{$\begin{array}{l}\text { First differences } \\
-6.164062\end{array}$} & \multicolumn{2}{|c|}{ Critical Values } & \multicolumn{2}{|c|}{ Order of Integration } & \multirow{3}{*}{ Stationary at at difiference } \\
\hline \multirow[t]{3}{*}{$\begin{array}{lll}\mathbf{C} & \mathbf{L} & \mathbf{A}\end{array}$} & & $1 \%$ & -3.615588 & & $1 \%$ & -3.621023 & \multirow{3}{*}{ I $\quad(1$} & \multirow{3}{*}{1 ) } & \\
\hline & & $5 \%$ & -2.941145 & & $5 \%$ & -2.943427 & & & \\
\hline & & $10 \%$ & -2.609066 & & $10 \%$ & -2.610263 & & & \\
\hline \multirow[t]{3}{*}{$\begin{array}{llll}\text { I } & \mathbf{N} & \mathbf{T} & \mathbf{R} \\
\end{array}$} & \multirow{3}{*}{-2.494077} & $1 \%$ & -3.626784 & \multirow{3}{*}{-6.2448} & $1 \%$ & -4.416345 & \multirow{3}{*}{\multicolumn{2}{|c|}{ I $\quad\left(\begin{array}{ll} & 1\end{array}\right)$}} & \multirow[t]{3}{*}{ Stationary a at 1 difference } \\
\hline & & $5 \%$ & -2.945842 & & $5 \%$ & -3.622033 & & & \\
\hline & & $10 \%$ & -2.611531 & & $10 \%$ & -3.248592 & & & \\
\hline \multirow[t]{3}{*}{$\begin{array}{lll}\mathbf{S} & \mathbf{A} & \mathbf{V}\end{array}$} & \multirow{3}{*}{-1.845400} & $1 \%$ & -3.615588 & \multirow{3}{*}{-6.672070} & $1 \%$ & -3.621023 & \multirow{3}{*}{\multicolumn{2}{|c|}{ I $\left(\begin{array}{ll} & 1\end{array}\right)$}} & \multirow[t]{3}{*}{ Stationaly at 1 1 difiference } \\
\hline & & $5 \%$ & -2.941145 & & $5 \%$ & -2.943427 & & & \\
\hline & & $10 \%$ & -2.609066 & & $10 \%$ & -2.610263 & & & \\
\hline \multirow[t]{3}{*}{ R G D P } & \multirow{3}{*}{1.856786} & $1 \%$ & -3.621023 & \multirow{3}{*}{-3.642986} & $1 \%$ & -4.226815 & \multirow{3}{*}{\multicolumn{2}{|c|}{ I $\quad\left(\begin{array}{ll} & 1\end{array}\right)$}} & \multirow[t]{3}{*}{ Stationary at at difference } \\
\hline & & $5 \%$ & -2.943427 & & $5 \%$ & -3.536601 & & & \\
\hline & & $10 \%$ & -2.610263 & & $10 \%$ & -3.200320 & & & \\
\hline \multirow[t]{3}{*}{ S M E Q } & \multirow{3}{*}{-3.177009} & $1 \%$ & -4.356068 & \multirow{3}{*}{-5.5025} & $1 \%$ & -4.226815 & \multirow{3}{*}{\multicolumn{2}{|c|}{ I $(1$}} & \multirow{3}{*}{ Stationary a a $1^{\ddagger}$ differerence } \\
\hline & & $5 \%$ & -3.595026 & & $5 \%$ & -3.536601 & & & \\
\hline & & $10 \%$ & -3.233456 & & $10 \%$ & -3.200320 & & & \\
\hline \multirow[t]{3}{*}{ A G R C } & \multirow{3}{*}{2.211635} & $1 \%$ & -3.615588 & \multirow{3}{*}{-4.838245} & $1 \%$ & -3.621023 & & & Stationary at $1^{\text {st }}$ \\
\hline & & $5 \%$ & -2.941145 & & $5 \%$ & -2.943427 & I & $1)$ & difference \\
\hline & & $10 \%$ & -2.609066 & & $10 \%$ & -2.610263 & & & \\
\hline D & & $1 \%$ & -4.309824 & & $1 \%$ & -3.621023 & & & Stationary a at 1 differencence \\
\hline & -1.840845 & $5 \%$ & -3.574244 & -8.321333 & $5 \%$ & -2.943427 & I $\quad($ & $1)$ & \\
\hline & & $10 \%$ & -3.221728 & & $10 \%$ & -2.610263 & & & \\
\hline
\end{tabular}

Source: Author's own computation using E-Views Software, Version 9.0

Table 4.2 presents the result of the unit root test using Augmented Dickey Fuller Test, the variables were all stationary at first difference as the critical value are significant at $5 \%$ level of significance respectively. This showed that if the variables are estimated in first difference the regression result will be free of spurious result.

\subsection{Error Correction Model}

We therefore formulate our supposed unrestricted ECM model from which we obtain efficient lag-length necessary for estimation thus: 


\section{Regression result}

Table 4.3 Regression analysis

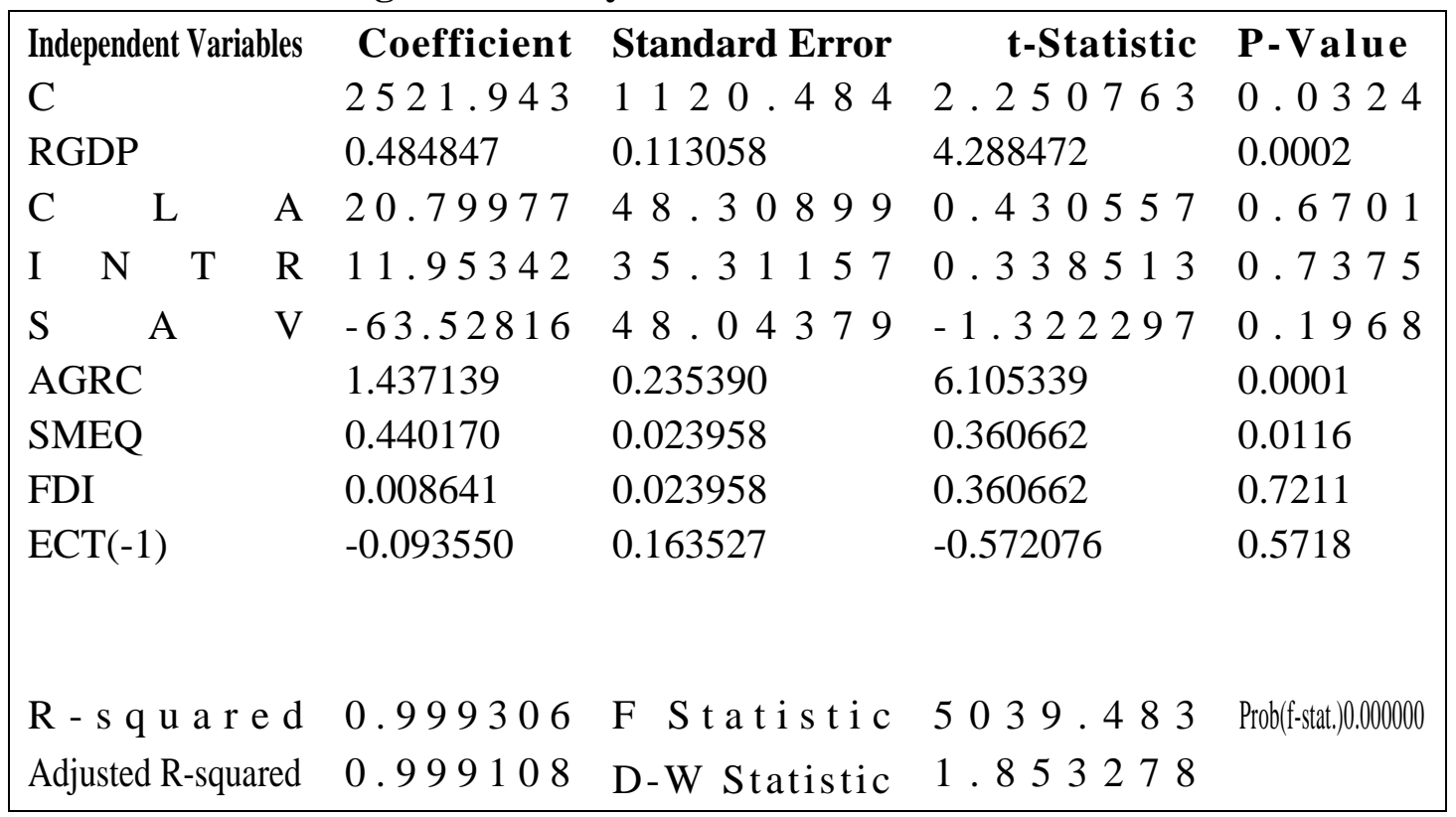

Source: Author's Computation (2021)

From the estimated regression result in table 4.3, the coefficients of the independent variables were both positively and negatively related to RGDP i.e. CLA, INTR, AGRC, SMEQ and FDI were positively related to RGDP while SAV was negatively related to RGDP. All the explanatory variables are jointly significantly to RGDP i.e predicator variables jointly explained $99.9 \%$ of GDP while the remaining $0.01 \%$ could be due to the effect of extraneous variables which are not captured in the model.

This result shows that a unit change in commercial loans and advances (CLA) will lead to 20.79977 increase in RGDP holding other variables constant. The result is in line with Afolabi (2011) who investigated the effect of SMEs financing on economic growth in Nigeria between 1980 and 2010. The estimated results from Afolabi revealed that SMEs output proxy by wholesale and retail trade output as a component of gross domestic product, commercial banks credit to SMEs and exchange rate of naira vis-à-vis U.S dollar exert positive influence on economy development proxy real gross domestic product. Therefore, emanating from the findings, the study proffered that the central authority should create an enabling environment for SME development.

Also, a unit change in interest rate (INT) will lead to11.95342 in RGDP holding others variables constant. The result also shows that a unit change in Agricultural contribution (AGRC) will lead to1.437139 increase in RGDP holding other variables constant. More so, a unit change in SMEQ will lead to 0.440170 increase in RGDP holding other variables constant. This result is equally in line with Agu and Okot (2011) who investigated the impact of small and medium scale enterprises on economic growth in Nigeria between the period 1980 and 2009. And their estimated results point out that small and medium scale enterprises have both positive and significant impact on economic development in Nigeria. 
However, the result equally shows that a unit change in foreign direct investment (FDI) will lead to 0.008641 increase in RGDP holding other variables constant. But on the contrary, the result shows that a unit change in Savings (SAV) will lead to decrease of 63.52816 in RGDP holding other variables constant. Therefore, the result is not in line with Snodgrass and Biggs (2014), who analyzed the impact of the Khushhali Microfinance Bank in Pakistan. The analysis demonstrated that participation in the scheme had positive impact on both economic and social indicators as well as income generating activities especially for the poor ones' economic activities. However, the behaviour of SAV to RGDP is not too surprising looking at the current situation of the economy. Currently, the country is experiencing "stagflation" i.e high rate of inflation coupled with high rate of unemployment is a clear indication that people will hardly save in this kind of current situation and the little saved was not channelled to investment.

\section{Error Correction Test}

Error correction test (ECT) helps us to measure the speed of Adjustment towards the equilibrium at the long run as a result of drift in equilibrium at the short run. After confirming the long run relationship among the variables from the unit root test in Table 4.3, then Error correction test enabled us to examine the speed of adjustment towards the long run equilibrium. Therefore, we took a step further to develop Error Correction Term ECT (-1). ECT (-1) is 0.093550 and it means that the speed of adjustment towards the long run equilibrium is approximately $9.3 \%$ i.e, the disequilibrium among the variables: RGDP, CLA,INTR, SAV, AGRC, SMEQ and FDI, will come back to equilibrium with the speed of 9.3\% which is very acceptable.

\subsection{Conclusion}

Developing countries like Nigeria need to pursue economic growth and development if they are to reduce mass poverty and unemployment through SMEs. To achieve this, economic growth is mainly targeted in the real sector of the economy. This is because the income of individuals and the country at large has to grow if the other components of development are to be achieved. The government has a big role to play in realizing this objective through its policies and strategies.

However, there is no consistent theory that supports the role of government in stimulating economic growth. Thus the study depended on secondary data, 1981 to 2019 to analyze the impact of small and medium scale enterprises on economic growth in Nigeria by using econometric techniques. The model in question was adequate as revealed by both Unit Root test and error correction model (ECM) which helped in analyzing the long run impact of the variables.

This study has been able to provide answers to the research questions based on the findings by clearly indicating that Small and Medium Scale enterprises (SMEs) have a positive and significant effect on the economic growth of Nigeria and long run impact on the economy. CLA has a positive and statistically insignificant impact on RGDP, SAV has a negative and statistically insignificant impact on RGDP, INTR has a positive and insignificant impact on RGDP, but AGRC had positive and significant impact on RGDP, while finally Foreign Direct Investment (FDI) has a positive but insignificant impact on RGDP in Nigeria. 


\subsection{Recommendations}

Based on the above findings and conclusion, some possible recommendations are as follows:

a) The different tiers of government should direct credit policies towards small and medium scale enterprises and intensity monitoring process to check inefficiency and ineffectiveness. This can be done through government expansionary policies; reducing interest rate and buying securities from member banks so as to make liquidity available to be given to SMEs through loans.

b) Government should pursue policies that ensure stability of the economy and sustainable growth, ensuring stable prices and a more realistic exchange rate. Some of these policies includes; Technology policy where government provides incentives for SMEs to invest into new technology. These incentives could be in form of grants, cheap loans, or tax relief.

c) Adequate infrastructure should be provided to ensure better output production and transported at lower costs as well as generating jobs and other positive externalities by the small and medium scale enterprises. This the government can achieve by increasing her spending in providing good roads, electricity and other necessary amenities.

d) Agricultural activities should be encouraged since it has a positive and significant impact on economic growth in Nigeria. Farmers should be given incentives to aid local production to foster economic growth. 


\section{References}

Afolabi, M., O. (2011)."Growth and Effect of Small and Medium Enterprises (SME) Financing in Nigeria”. Journal of African Macroeconomics review,3(1).

Agu, C., C. and Okot, B., C. (2011). "Impact of Small and Medium Enterprises on Economic Growth in Nigeria". Journal of humanities and social sciences, 6(1).

Akinruwa, T. E., Ibojo, B., O and Awolusi, O., D. (2013).' 'Determinants of Small and Medium Enterprises (SMEs) Performance in Ekiti State, Nigeria”: A Business Survey Approach. European Journal of Humanities and Social Sciences, 7(1).

Asta, L. and Zaneta, S. (2010). "Sustainable Development and Decision Making Model for Small and Medium Enterprises". Environmental Research, Engineering and Management 2(52), 14-24.

Bello, A., Jibir, A., and Ahmed, I. (2018). Impactof Small and Medium Scale Enterprises on Economic Growth:Evidence from Nigeria. Global Journal of Economics and Business, 4(2),236-244.

Cabello, N., T. (2010). "SMEs in the U.S and Japan". A paper presented on a forum, "Looking at SMEs in some developed countries". International Journal of Management and Information Systems, 15(2), 95-104.

Central Bank of Nigeria (2014).Annual Economic Report 155w 1597-2976. $31^{\text {st }}$ December, 2014, Abuja.

Central Bank of Nigeria (2015). Statistical Bulleting and Financial Review. December 15,26.

Etebefia, S., O. and Akinkunmi, W., B. (2013). "Contribution of Small and Medium Enterprises to Economic Growth". Standard Research Journal of Business Management, 1(2), 60-71.

Gujarati, D., N. (2001). Econometria. Mexico: McGrawhill, USA.

Odeyemi, J., A. (2003). An Overview of the Current State of SMEs in Nigeria and the Need for Intervention. A Paper Presented at the National Summit on SMIEIS Organised by the Bankers ${ }^{e}$ Committee and Lagos Chambers of Commerce and Industry (LCCI), Lagos, 10th June, 2003.

Olutunla, G., T. and Obamuyi, T., M. (2008). An Empirical Analysis of Factors Associated with the Profitability of Small and Medium - Enterprises in Nigeria. African Journal of Business Management, 2(x), 195-200.

Onakoya, O., A. (2011). Small and Medium scale Enterprises, Financing and Economic Growth in Nigeria. Retrieved from www.academia.edu.

Onyeiwu, C. (2010). Small and Medium Enterprises Finance and Economic Development of Nigeria. Referenced from www.unilag.edu.ng/opendoc.

Otugo, N., E., Edoko, T., D., and Ezeanolue, U., S. (2018). Effect of Small and Medium Enterprises on Economic Growth in Nigeria. Sumerianz Journal of Business Management and Marketing, 1(2), 73-78. 
National Bureau of Statistics (NBC, 2009). Issues and Publication.

Muritala, T., A.Awolaja, A., M and Bako, Y., A. (2012). "Impact of Small and Medium Enterprises on Economic Growth and Development".American Journal of Business and Management, 1(1),18-22.

Ojo, O. (2009). "Impact of microfinance on entrepreneurial development: The case of Nigeria". The international conference of Administration and Business, ICEA - FAA Bucharest,536-545.

Reavley, M., A and Lituchy, T., R. (2008). Successful Women Entrepreneurs: A Six-Country Analysis Of Self Reported Determinants of Success More Than Just Dollars And Cents. International Journal of Entrepreneurship and Small Business, 5(3-4), 272296.

Safiriya, A., M and Njogo, B., O. (2012). "Impact of Small and Medium Scale Enterprises in the generation of Employment in Lagos State". Kuwait Chapter of Arabian Journal of Business and Management Review, 1(11), 107-141.

Snodgrass, J., E., and Biggs, U. (2014). "Financial Management, Public and the East Asian Miracle'. World Bank Research Observer, 11(2).

Solow, R., M. (1974). "The economics of resources or the resources of economics". The American Economics Review, Special issues papers and proceedings of the EightySixth Annual meeting of the American Economic Association,6.1(2), 1-14. 


\section{APPENDIX}

\section{Data Used for Analysis}

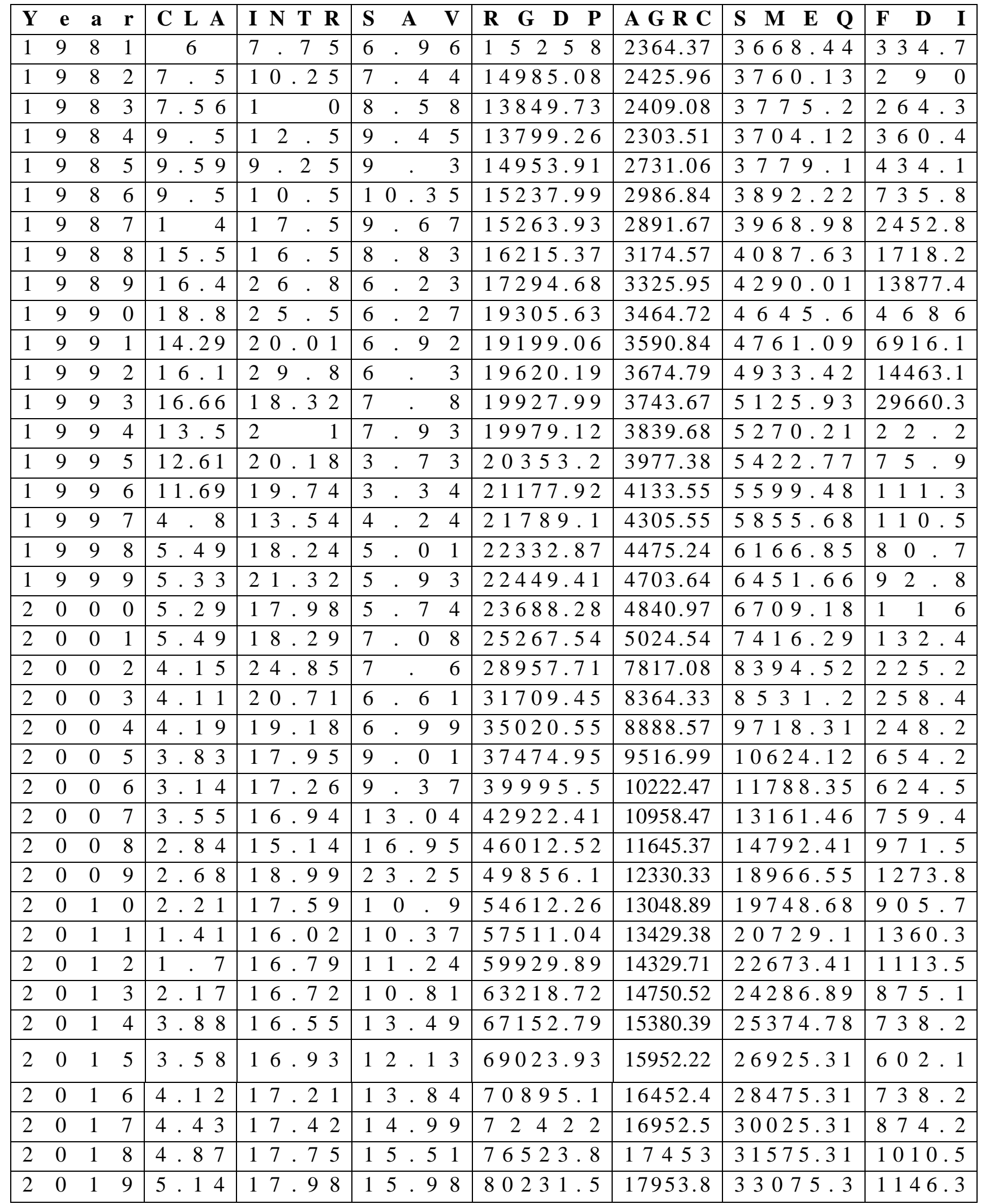

Source: CBN Statistical Bulletin, Volume 28, 2020. 